\title{
Systemic Transplantation Effect of Human Adipose Tissue Derived Mesenchymal Stem Cells on Cognitive Deficits and Hippocampal Antioxidant Capacity in Trimethyltin Model of Alzheimer's Disease
}

\author{
Mohammad Amin Edalatmanesh ${ }^{1 *}$, Samireh Nemati ${ }^{1}$, Habibollah Khodabandeh ${ }^{1}$ \\ ${ }^{1}$ Dept of Biology, College of Sciences, Shiraz Branch, Islamic Azad University, Shiraz, Iran
}

Article Info

Article type:

Research article

\section{Article History:}

Received: 01 February 2021

Revised: 21 February 2021

Accepted: 24 July 2021

\section{* Correspondence to:}

Mohammad Amin Edalatmanesh Dept of Biology, College of Sciences, Shiraz Branch, Islamic Azad University, Shiraz, Iran Email:

amin.edalatmanesh@gmail.com

\author{
A B S T R A C T
}

Introduction: Stem cell-based therapies create new hope for the treatment of Alzheimer's disease (AD). Since the mesenchymal stem cells have neuroprotective and regeneration effects, this study aimed to investigate the memory, learning, and antioxidant capacity of the hippocampus following human adipose-derived mesenchymal stem cell (Ad-MSC) transplantation in Trimethyltin (TMT) rat's model of AD.

Material \& Methods: In total, 24 male Wistar rats were randomly divided into three groups (8 animals per group) of control (without any treatment), TMT+PBS (Trimethyltin+Phosphate buffer saline), and TMT+Ad-MSC (Trimethyltin+Stem cells). For the induction of the AD, TMT was peritoneally injected $(8 \mathrm{mg} / \mathrm{Kg})$. After $48 \mathrm{~h}$, the TMT+AdMSC group received 1 million stem cells intravenously. One month after transplantation, avoidance and working memories were evaluated. Afterward, hippocampal levels of superoxide dismutase (SOD), catalase (CAT), glutathione peroxidase (GPX), and malondialdehyde (MDA) were measured using ELISA.

Findings: The results showed a significant increase in the percentage of correct motor frequency in the Y maze, a decrease in the spent time in the dark room $(\mathrm{P}<0.05)$, and an increase in the latency time to the dark room in the TMT+Ad-MSC group, compared to the TMT+PBS group $(\mathrm{P}<0.01)$. Moreover, a significant increase in the CAT, SOD, and GPX enzymes activity, as well as a decrease in the MDA level in the hippocampus were observed in the TMT+Ad-MSC group, compared to the TMT+PBS group $(\mathrm{P}<0.05)$.

Discussion \& Conclusion: Xenotransplantation of human adipose tissue stem cell improved learning and memory, reduced tissue oxidative stress, and increased hippocampal antioxidant capacity in an animal model of AD.

Keywords: Alzheimer's disease, Memory, Mesenchymal stem cells, Oxidative Stress, Rat

$>$ How to cite this paper

Edalatmanesh MA, Nemati S, Khodabandeh H. Systemic Transplantation Effect of Human Adipose Tissue Derived Mesenchymal Stem Cells on Cognitive Deficits and Hippocampal Antioxidant Capacity in Trimethyltin Model of Alzheimer's Disease. Journal of Ilam University of Medical Sciences. 2022;29(5): 32-43. 
مقدمل: درمانهاى مبتنى بر سلولهاى بنيادى اميد تازهاى در درمان بيمارى آلزايمر ايجاد كردهاند. ازآنجاكه سلولهاى بنيادى مز انشيمى آثار حفاظت و بازسازى عصبى دارند، هدف اين مطالعه ارزيابى حافظه، يادگيرى و ظرفيت آنتى اكسيدانى

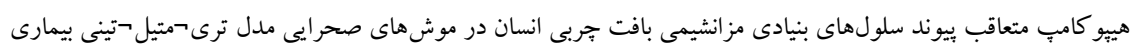
آلزايمر است.

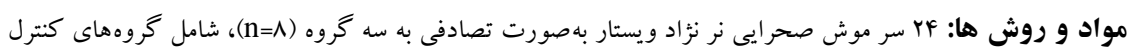

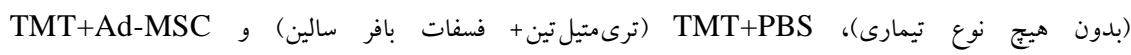

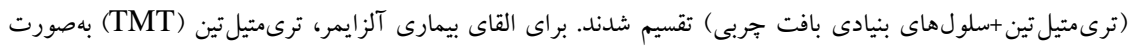

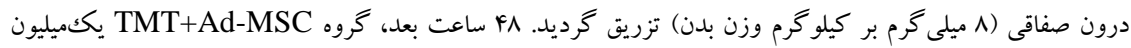

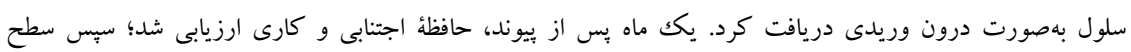

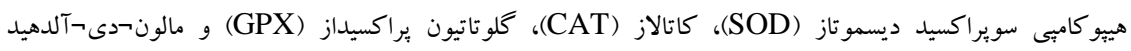

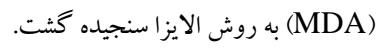

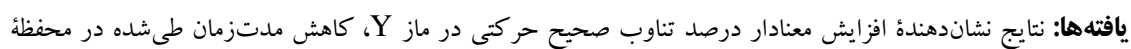

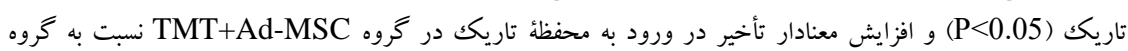

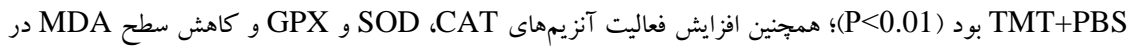

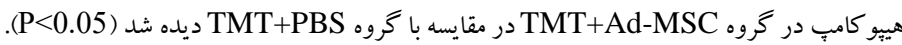

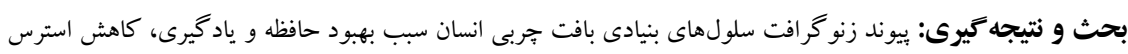
اكسيداتيو بافتى و افزايش ظرفيت آنتىاكسيدانى هييو كامب در مدل حيون حيو انى بيمارى آلز ايمر كرديد.

جكده

اثر بيوند سيستميك سلول هاى بنيادى مز انشيمى بافت جربى انسان بر اختلالات شناختى و ظرفيت آنتىاكسيدانى هييوكامٍ در مدل ترى حمتيل تينى بيمارى آلزايمر

\author{
محمدامين عدالت منش '] iD ، سميره نعمتى '، حبيباله خدابنده'
} 'خروه زيستشناسى، دانشكده علوم، دانشگاه آزاد اسلامى، واحد شيراز، شير از، ايران اطلاعات مقاله 
مىشود. مسموميت با ترىمتيلتين سبب آسيبذيذيرى انتخابى نورونها مى گردد كه آسيب سيستم ليمبيك و و بهويزه هييو كامب را در بر دارد. بِاتولوزى تحليل عصبى القاشده با ترىمتيلتين با مركَ سلولى گسترده، اختلالات ميتو كندريايى، استرس اكسيداتيو، التهاب عصبى، سميت

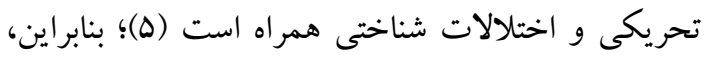
مسموميت با ترىمتيلتين بهعنوان يكك مدل تجربى در مطالعه اختلالات شبهبيمارى آلزايمر مفيد است. استرس اكسيداتيو ناشى از TMT، با توليد گونهاي فعال اكسيزن (ROS) و نيتروزن (RNS) و يراكسيداسيون لييدى (ROS) مشص مىشود، درحالى كه آسيب ميتو كندريايى احتمالاً نتيجة برهم كنش TMT با بروتئين استانين است كه به آزادسازى سيتو كروم C و فعاليت آبشار آنزيمى كاسباز منجر مى گردد (9). هرجند مطالعاتى درباره اثر ييوند

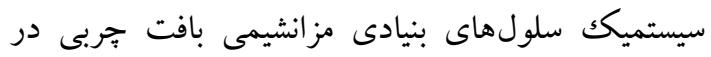

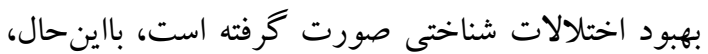
هنوز يُرسهاى مختلفى دربارة سازو كار اثر گذارى

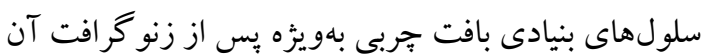

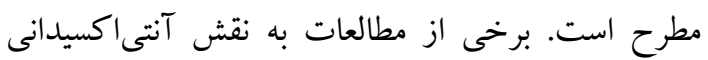

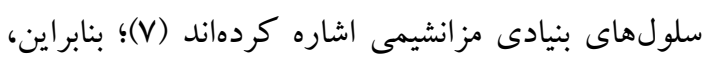

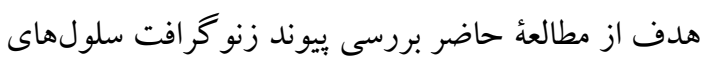

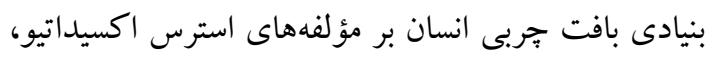

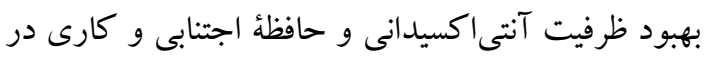
موشهاى صحر ايى مدل بيمارى آلزايمر است.

\section{مواد و روش ها}

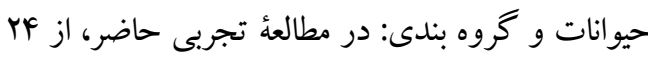

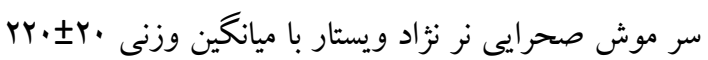

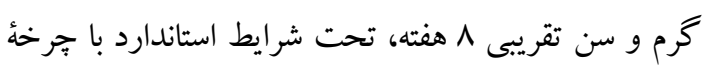

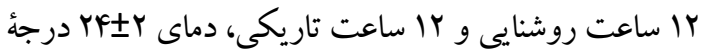

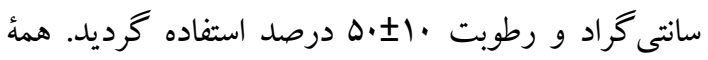

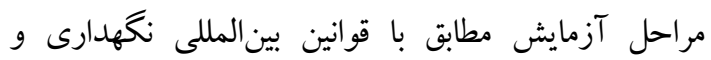
مراقبت از حيوانات و با نظارت كميته اخلاقى دانشكاه آزاد
بيمارى آلزايمر شايعترين شكل زوال عقل است كه علائم بالينى ازجمله نداشتن حافظه و اختلال عملكرد شناختى را نشان مىدهد. تجمع قطعات يِيتيدى بتا آميلوئيد به بروز اختلالات حركتى، شناختى و مركى نورونى در

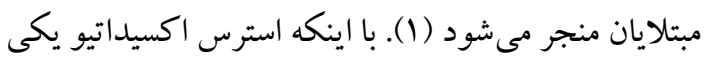
از عوامل ايجادكنندة اختلالات نورودزنراتيو است و علاوه بر اختلالات شناختى كه نشانه اصلى بيمارى آلزايمر محسوب مىشود، همراهى ساير بيمارىهاى

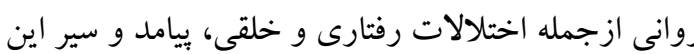
بيمارى را رو به وخامت مىبرد و درمان اين اختلالات نيز خود توجه بالينى خاصى را مىطلبد (Y). با وجود يشرفتهاى فراوانى كه در زمينهاى مختلف بز شكى ترميمى صورت گرفته است، تاكنون درمان قطعى براى اختلالات نورودزنراتيو وجود نداشته است. بالينحال، در سالهاى اخير رويكرد استفاده از سلولهاى بنيادى در درمان بيمارىهاى عصبى اميدواركننده بوده است. سلولهاى بنيادى سلولهاى تمايزنيافتهاى هستند كه با قرار كرفتن در شرايط مناسب، قابليت تمايز به ردههاى مختلف

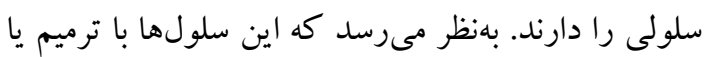
جايخزين شدن در بافتهاى صدمهديده، نقطة عطفى در

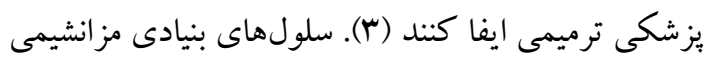

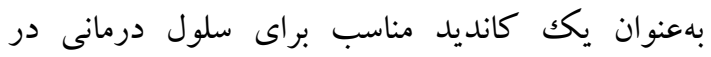
بيمارىهاى عصبى معرفى شدهاند. اين سلولها با توليد

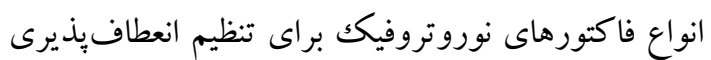

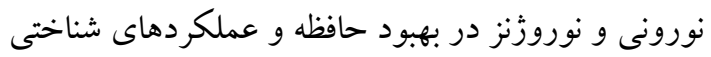
در مدلهاى حيوانى بيمارى آلزايمر نقش مهمى داشتهاند.

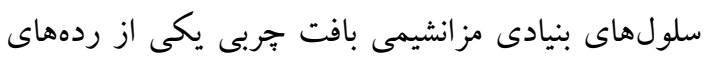
سلولى جذاب در طب ترميمى است كه قادر به بيان زنحهاى بيشحساز عصبى و داراى توانايى تمايز به سلولهاى شبهعبى هستند (F). ترىمتيلتين كلرايد (Trimethyltin; TMT) يك نوروتوكسين نيرومند است كه سبب ايجاد اختلالات رفتارى- شناختى در انسان و حيوانات آزمايشگاهى 
$$
\text { برديدند (دو بار در هفته). يس از آديو اروز، تمايز سلولها }
$$

Oil-Red O (Sigma, به آديبوسيت با رنكگ آميزى

Germany)

استخوان يس از الب روز، با رنگكآميزى قرمز آلزارين

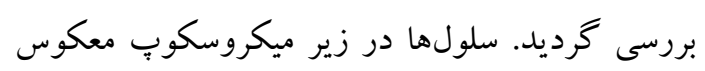
مشاهده شدند. در رنغكآميزى (Olympus, Japan) آدييوسيت، مسبب قرمزرنگ شدن شدن قطرات جربى موجود در آديبوسيتها مىشود، درحالى كه قرمز آلزارين (Sigma, Germany) با اتصال به يونهاى كلسيم حاصل از سلولهاى استئوبلاست، در محيط كشت به

رنخك قابل تشخيص يديدار خواهد شد (9). القاى مدل و وييوند سلول: براى القاى مدل بيمارى

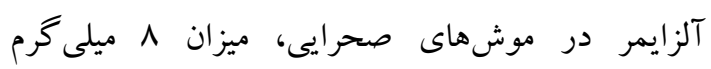

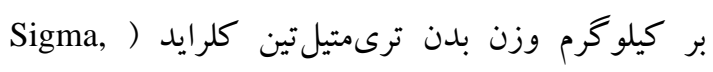
(Germany و TMT+PBS مسموميت بTMTL ، حيوانات علائمى نظير كرختى، يرخاشخرى، افزايش دماى بدن و تشنج را يس از تزريق

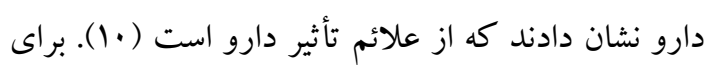
تأييد مدل، از آزمون شاتل باكس استفاده شد و با تأييد اختلال شناختى در نمونههاى تصادفى هر گرووه، تيمار با سلولهاى بنيادى آغاز گرديد.
IR-91-YDIF-IYF اسلامى واحد شيراز به شماره مجوز IIAUSHIRAZ-

بس از تهيه حيوانات از مركز تكثير و نخهدارى

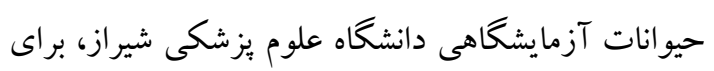
ساز گارى با محيط جديد، يكك هفته در شرايط آزمايشگاه تخصصى علوم جانورى دانشگاه آزاد اسلامى شيراز قرار گرفند؛؛ سيس بهصورت تصادفى، به سه گروه هشت تائى شامل گروه كنترل (بدون هيج نوع تيمارى)، گروه دريافت كننده ^ ميلى گرم بر كيلو گرم وزن بدن TMT و فسفات بافر سالين بهعنوان حامل سلولهاى

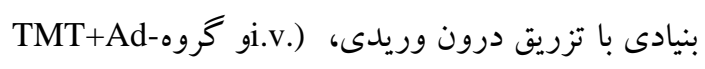
MSC (

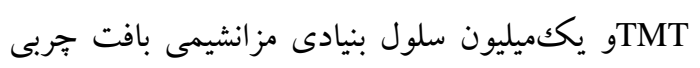
انسان، (i.v. (9قسيم شدند (9). استخراج و تعيين هويت سلولهاى بنيادى مزانشيمى بافت جربى انسان: نمونهُ بافت جربى به روش جراحى لاييو ساكشن از يكك زن سالم بr ساله و از سوى جراح در بيمارستان جمع آورى گرديد؛ سبس نمونه ها بر روى يخ و و در كمترين زمان به آزمايشگاه منتقل شدند. نمونههاى بافت جربى ع-ه بار با فسفات بافر سالين (PBS,Gibco)

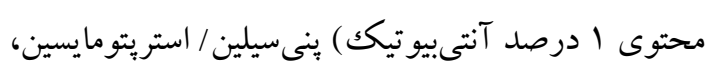
شiosera)

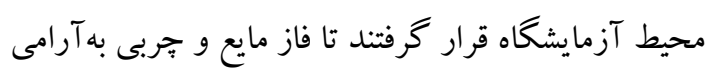
از يكديخر جدا كردند. فاز مايع دور ريخته شد و هضم كلازنازى بافت جربى با استفاده از كلازناز / / • درصد

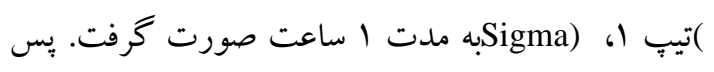
از سانتريفيوز نمونههاى بافتى هضمشده با دور 5000 rpm در زمان ه دقيقه، سلولهاى باقىمانده در كف لوله آزمايش در محيط كشت (DMEM, Gibco) حاوى رمان درصد سرم جنينى كاو (FBS, Gibco) و و 1 درصد آنتىبيوتيكك كشت گرديد (9). سلولها بس از رسيدن به تعداد مناسب در ياساز سوم، براى بيوند آمادهسازى شد. براى اثبات بنيادى بودن سلولهاى مستخرج از بافت جربى، از سنجش ظرفيت آديبوزنزى و استئوزنزى 
ورودهاى موفق، ورودهاى متناوب و رِشتسرهم و

سريالى در هر سه بازو است (11). ارزيابى حافظة اجتنابى: آزمون حافظة اجتنابى غيرفعال

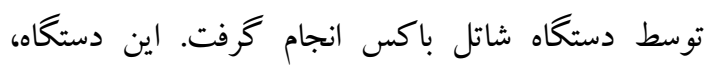
جعبهاى از جنس بيلكسى گلاس شامل دو محفظة روشن و و

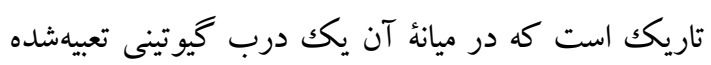

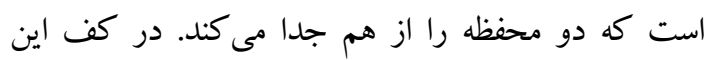

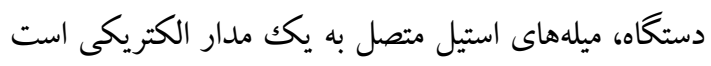
كه با روشن شدن كليد مدار، جريان الكتريكى با مدت،

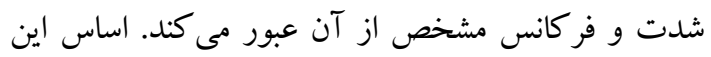

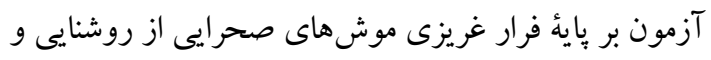

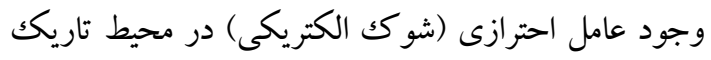

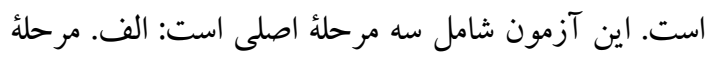

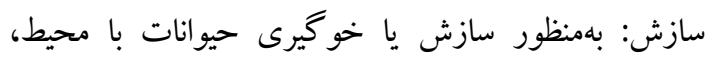

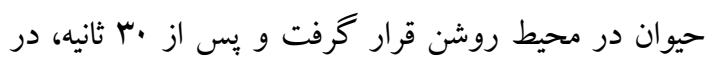

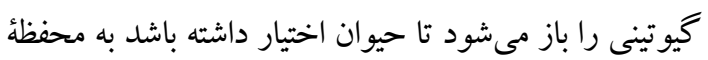

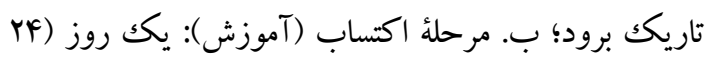

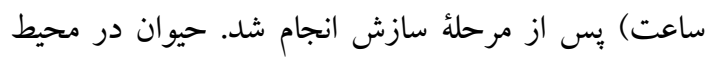

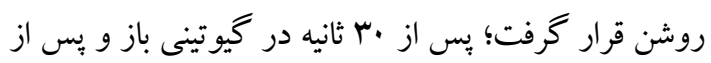
ورود حيوان به محيط تاريك در بسته و شوكى (Y ميلى آمبر،

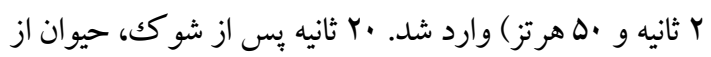

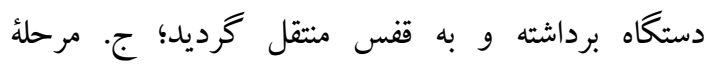

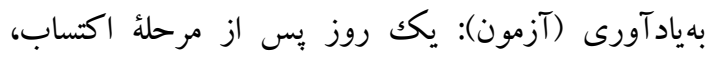

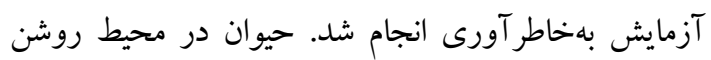

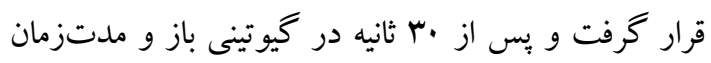

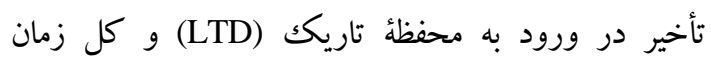
سبرىشده در محفظةٌ تاريك (STD) ثبت گرديد. در اين

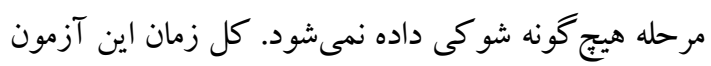

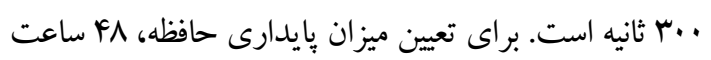

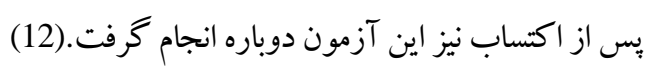

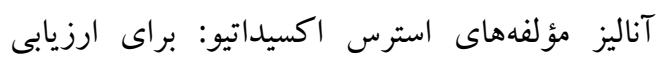

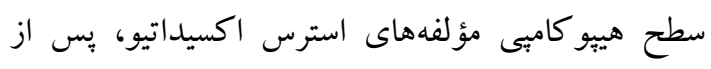

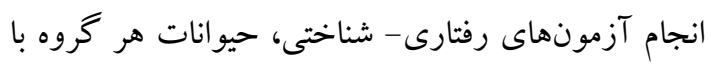
استنشاق كاز كلروفورم در دسيكاتور بيهوش و بلافاصله

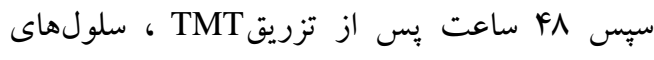

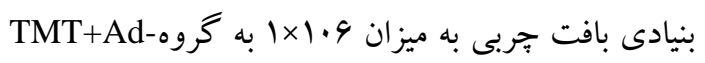

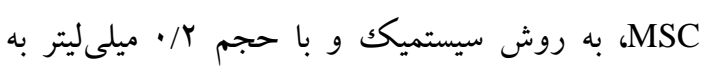
همراه حامل PBS از طريق وريد زو گولار تزريق شد. براى تزريق سيستميك سلولهاى بنيادى، حيوانات با بان

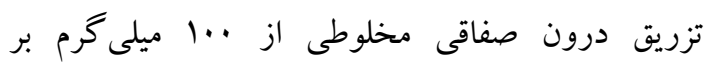

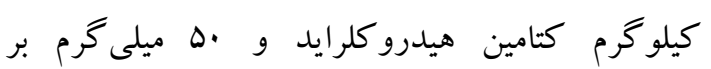

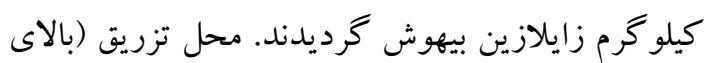

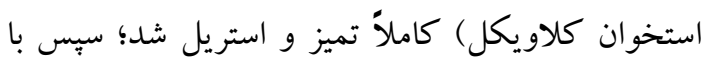
ايجاد برش كو جكك به طول نيم سانتىمتر و بدون آسيب

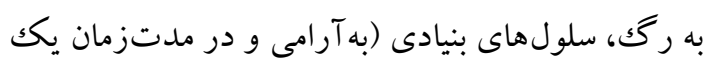

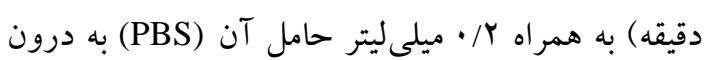

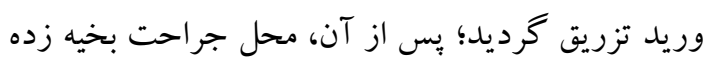
شد و حيوان به قفس ريكاورى منتقل گرديد. يكك ماه پس از تزريق سلولهاى بنيادى، آزمونهاى رفتارى صورت گرفت (9). با توجه بهدقت در تزريق TMT و

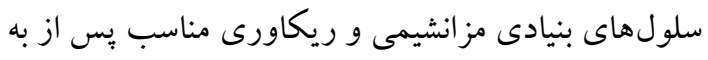

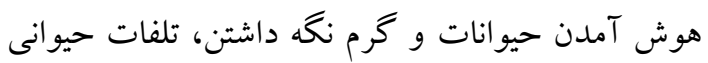
مشاهده نشل. ارزيابى حافظةٌ كارى: براى سنجش حافظة كارى از آزمون ماز Y استفاده گرديد. اين ماز از سه بازو به ابعاد يكسان شبيه به حرف Y تشكيلشده است. هر بازو ابعاد

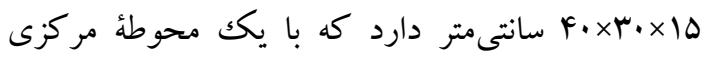

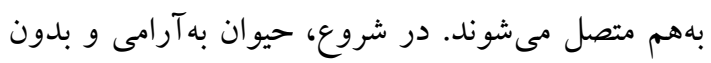

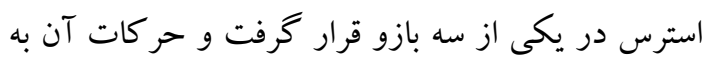
مدت ها دقيقه مشاهده گرديد. تعداد دفعات ورود حيوان

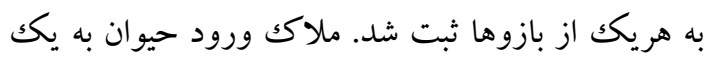

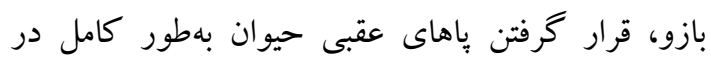
داخل بازو بود. رفتار تناوب بهعنوان ورودهاى موفق و بهاي

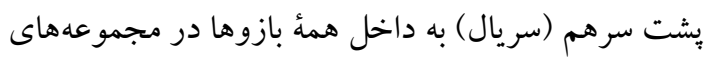

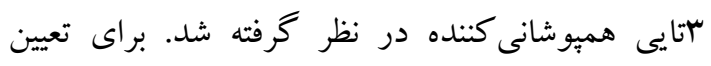
ميزان حافظة كارى، درصد رفتارهاى تناوبى از حاصل

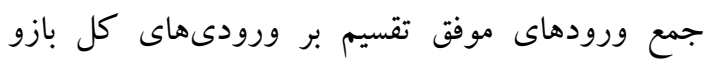

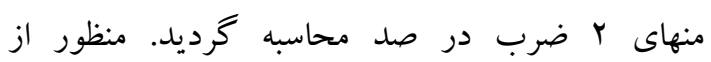


rv

آناليز آمارى و تحليل دادهها: اطلاعات بهدست آمده از

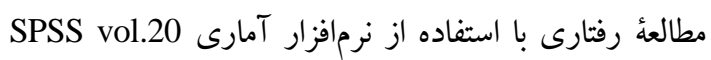
آناليز شد. بِ از تأييد توزيع طبيعى دادهحها به كمكك آزمون كلمو گروف اسميرنوف، با استفاده از آزمون آناليز واريانس يكك-طرفه (One-Way ANOVA) و آزمون تعقيى Tukey به مقايسٔ گروههاى مدنظر برداخته شد. مقادير بهصورت ميانگين و انحراف معيار و حداقل سطح معنادارى (P<0.05) در نظر كرفته شد.

\section{يافته ها}

ارزيابى ماهيت سلولهاى بنيادى: با توجه به مشاهده

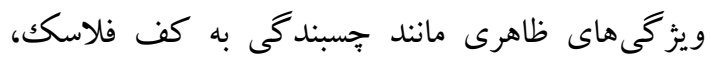
مورفولوزى دوكى و شبهفيبروبلاستى سلولها (شكل شمارهُ ا. A)، تمايز به آدييوسيت (شكل شمارهٔ ا. B) و و تمايز به استئوسيت (شكل شمارهُ ا. C) نشان داده شد كه سلولهاى مستخرج از بافت جربى انسان ماهيت سلولهاى بنيادى مزانشيمى را دارند. fl روز يس از كشت سلولها در محيط آديبوزنيكك، حضور قطرات جربى به علت تمايز سلولهاى بنيادى مزانشيمى به آديبوسيتحهاست كه با

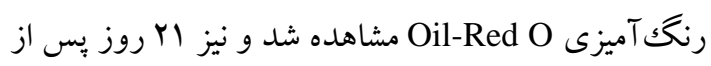
تيمار سلولها در محيط استئوزنيك، مشاهدهُ ماتريكس

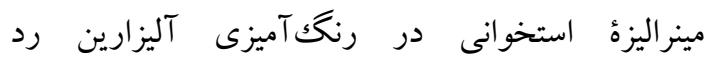
نشاندهندة ماهيت سلولهاى بنيادى مزانشيمى سلولهاى حاصل بود (شكل شمارة (1).
سر آنها با دستكاه گيوتين مخصوص جوند گان جدا كرديد. مغز از جمجمه خارج شد و بهسرعت بر روى يخ قرار كرفت. هيبو كامٍ با دقت در زير استريوسكوب از بقيه بخشهاى مغز جدا كرديد. (Olympus, Japan) يس از شستشو با محلول نرمال سالين به همراه بافر تريس

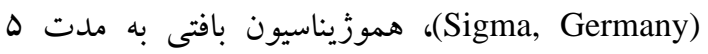
دقيقه با دستخاه هموزنايزر (IKA, Germany) با ... دور در دقيقه انجام شد. محلول حاصل به همراه ه/ • Sigma-Aldrich, ) ميلىمولار فنيلمتيل سولفونيلفلورايد (Germany سانتريفيوز يخجالدار (Hermle, Germany) سانتريفوز كرديد و سبس ميزان بافتى عوامل استرس اكسيداتيو در محلول رويى سنجيده شد (س) برسئ. به كمكك روش الايزا و با استفاده از كيتحهاى شر كت FineTest ، سطح هيبو كاميى فعاليت آنزيمهاى

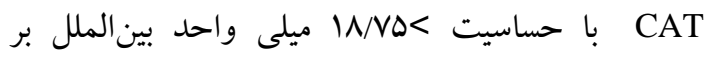

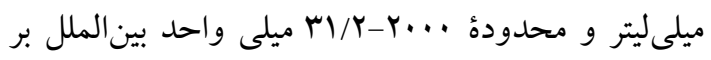

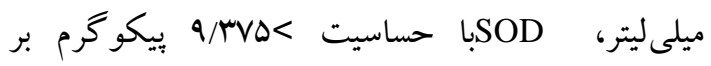
ميلى ليتر و محدوده . . . 1-10/4 بيكو گرم بر ميلى ليتر، GPX

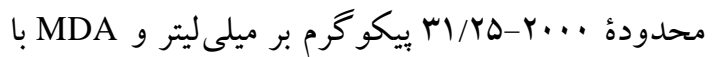
حساسيت >

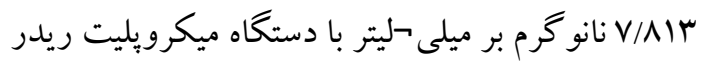
سنجيده گرديد. Stat Fax 2100, USA)
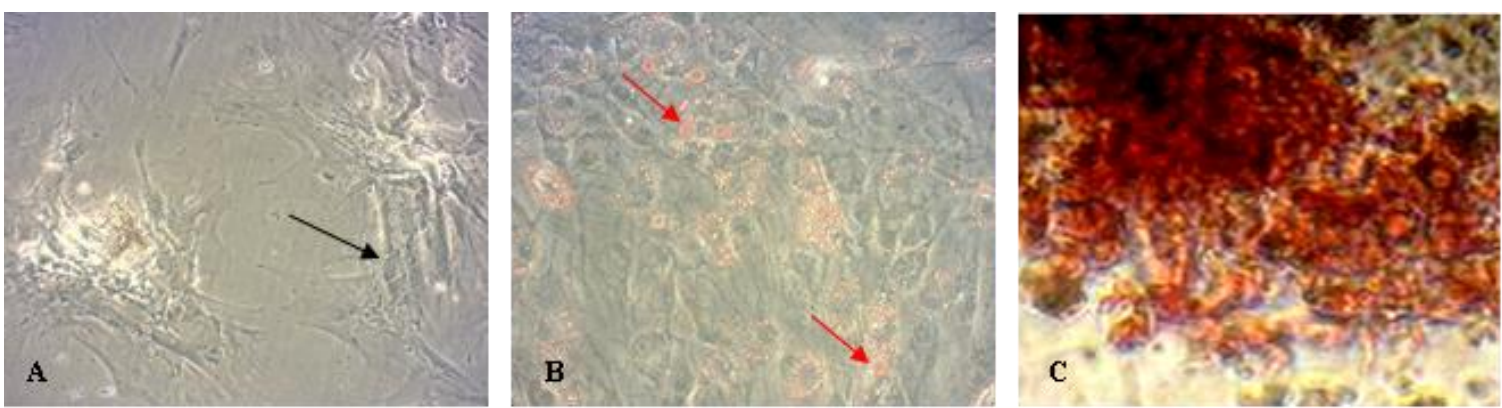

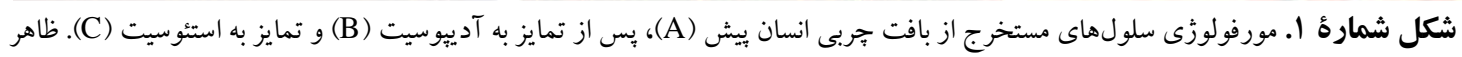

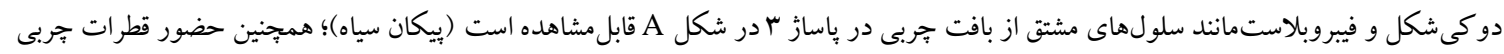

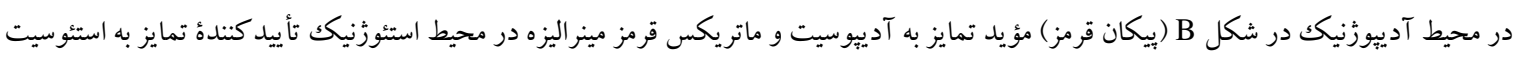

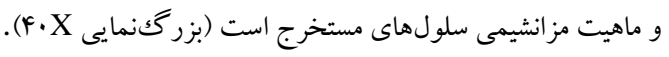




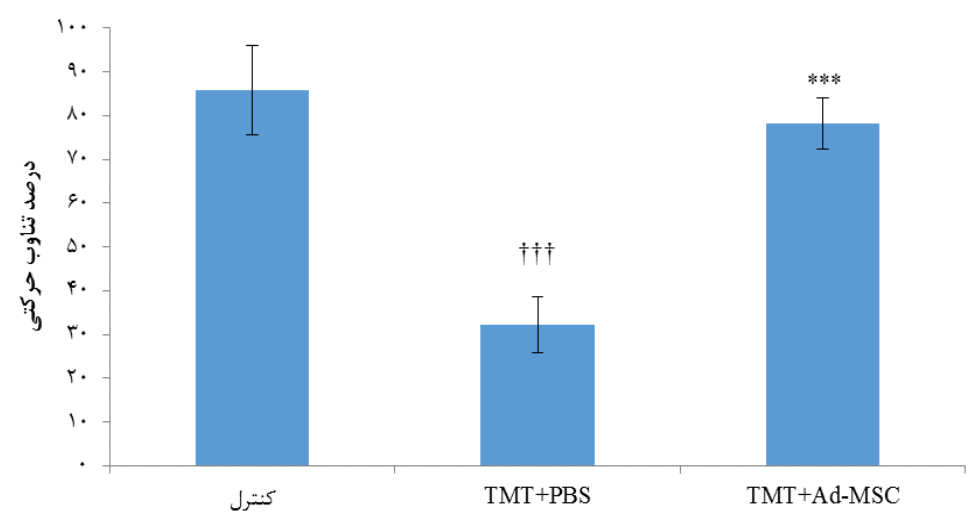

شكل شمارؤ r. مقايسٔ ميانكين Iانحراف استاندارد درصد تناوب صحيح حر كتى در گروهوهاى مختلف. نتايج نشان داد كه ميان كروه

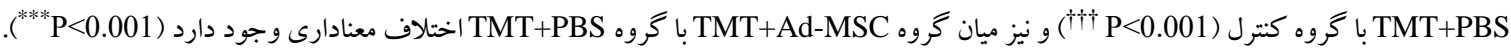

معنىدار تأخير در ورود به محفظة تاريك MF ساعت

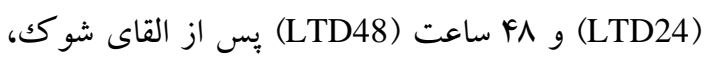
در خروه TMT+PBS نسبت به گروه كنترل ديده شد

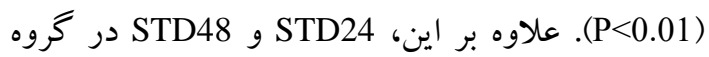
TMT+PBS در مقايسه با كروه TMT+Ad-MSC كاهش معنادارى داشته است (P<0.001). از سويى، دمبه (P<0.01) LTD48 ( $)$ (P<0.05) LTD24

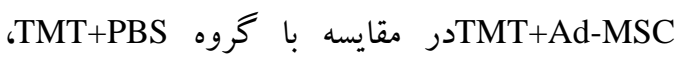

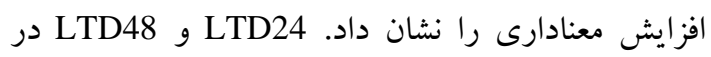
كروه TMT+Ad-MSC و در مقايسه با گروه كنترل، تغيير معنادارى را نشان نداد. جزئيات نتايج در جدول شمارة ا نشان دادهشده است. ارزيابى مؤلفههاى استرس اكسيداتيو: نتايج بهدستآمده از سنجش مؤلفهاى استرس اكسيداتيو

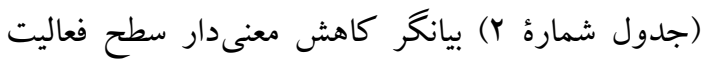

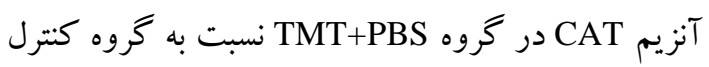

آزمون حافظة كارى: نتايج مطالعه حاضر نشان داد كه درصد تناوب صحيح حركتى در ماز Y در كرون كاهش معنادارى نسبت به كروه كنترل

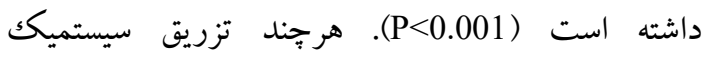
سلول هاى بنيادى مز انشيمى بافت جربى انسانى سبب بهبود

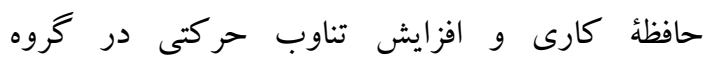
TMT+Ad-MSC نسبت به گروه TMT+PBS شده است

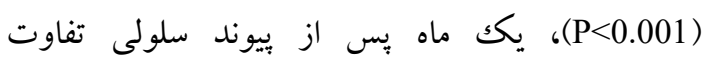

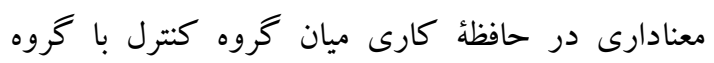
دريافت كننده سلول ديده نشد (شكل شماره ب). آزمون حافظة اجتنابى غيرفعال: نتايج بهدست آمده از

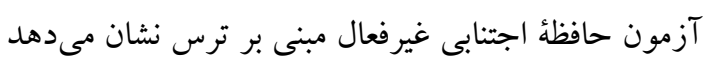

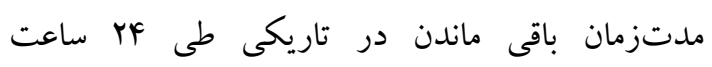

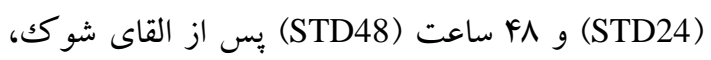
در گروه TMT+PBS و در مقايسه با گروه كنترل افزايش

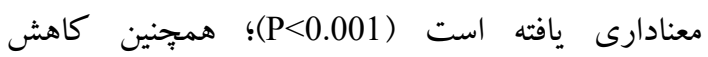

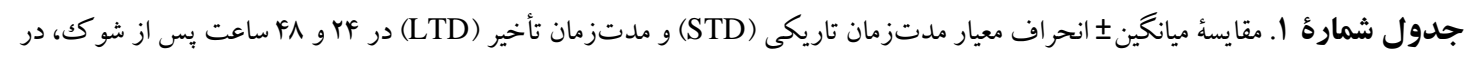

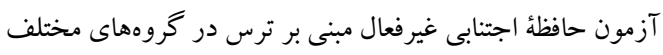

\begin{tabular}{|c|c|c|c|}
\hline TMT+Ad-MSC & TMT+PBS & كنترل & مؤلفهها / كروهها \\
\hline 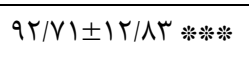 & $I V T / T \cdot \pm r \Delta / 1 \Delta^{\dagger+\dagger}$ & $G \Delta / \Delta \wedge \pm 1 Y / 9 r$ & STD24 \\
\hline 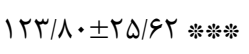 & & $\Lambda G / T F \pm I F / V \Lambda$ & STD48 \\
\hline $1.9 / V T \pm 1 \% / 19 *$ & $\Lambda 1 / \Delta \Lambda \pm 1 \cdot / \Lambda F^{\dagger}$ & 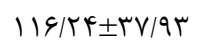 & LTD24 \\
\hline$\Lambda \varepsilon / \curlyvee q \pm \mid r / \wedge \varphi_{*} * * *$ & $F r / 91 \pm 11 / 9 . \dagger$ & $q 1 / \cdot q \pm r \Delta / r V$ & LTD48 \\
\hline
\end{tabular}

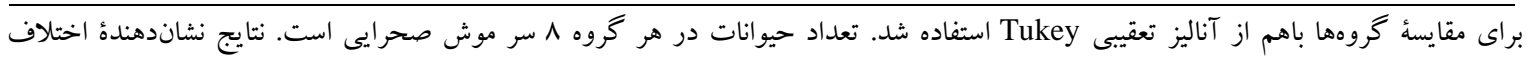
معنى مار ميان كروه TMT+PBS با كروه كنترل (TMT . (* $\left.\mathrm{P}<0.05,{ }^{* * *} \mathrm{P}<0.01,{ }^{* * *} \mathrm{P}<0.001\right)$ 


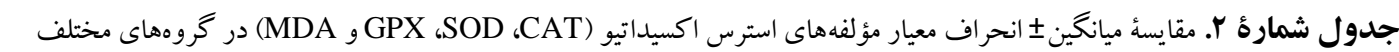

\begin{tabular}{|c|c|c|c|}
\hline TMT+Ad-MSC & TMT+PBS & كنترل & مؤلفهها / كروهها \\
\hline$V r / 11 \pm \Delta / \mu F_{*}{ }^{*}$ & $\Delta 1 / 9 \pm \wedge V / F \Delta \dagger \dagger \dagger$ & $|r V / A \pm r F / r|$ & CAT (mIU/ml) \\
\hline$\Delta V / 91 \pm F / r r * * *$ & $r V / F \pm \Delta I / r F \dagger \dagger \dagger$ & $90 / 9 \pm r F / 91$ & $\mathrm{SOD}(\mathrm{pg} / \mathrm{ml})$ \\
\hline$q V / \Delta \Delta \pm V / \Lambda I *$ & $F V / 90 \pm 9 / 49 \dagger \dagger \dagger$ & $1 \cdot V / 11 \pm 9 / 0 \mathrm{~A}$ & GPX (pg/ml) \\
\hline$\Delta \varphi / r V \pm N / 10 * *$ & $\Delta \varepsilon / \cdot \Delta \pm \Delta / 91 \dagger \dagger \dagger$ & $r \mid / F I \pm r / \cdot v$ & $\operatorname{MDA}(\mathrm{ng} / \mathrm{ml})$ \\
\hline
\end{tabular}

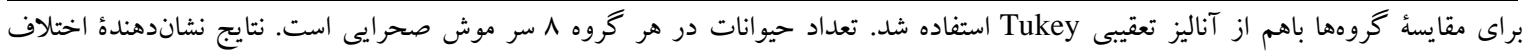

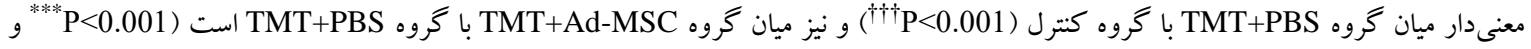
.( $\mathrm{P}<0.05,{ }^{* * *} \mathrm{P}<0.01$

كه ييوند زنو گرافت سلولهاى بنيادى بافت جربى انسان

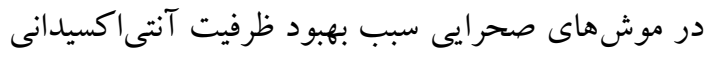
هييو كامب، افزايش فعاليت آنزيمهاى آنتىاكسيدانى

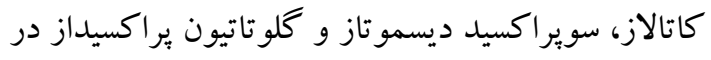

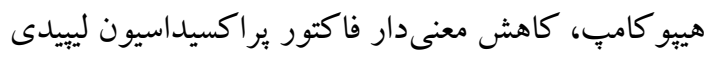

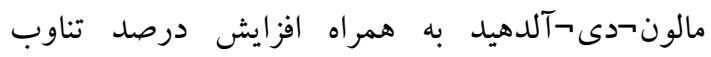
حر كتى كه نشاندهندة حافظة كارى در ماز Y است و نيز

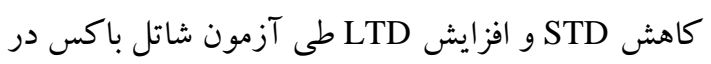

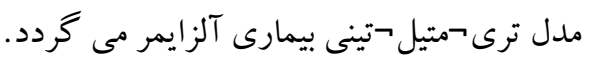

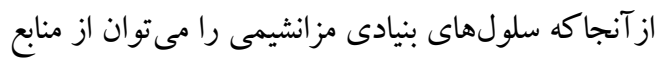

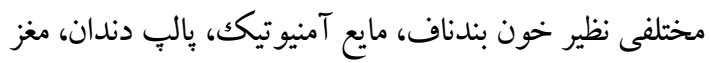

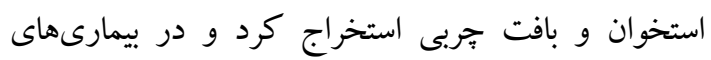
نورودزنراتيو به كار برد، مطالعة حاضر نشان داد كه سلولهاى بنيادى استخراجشده از بافت خربى انسان قابليت بهبود اختلالات شناختى در مدل بيمارى آلزايمر را دارند. درواقع، لئل سلولهاى بنيادى مزانشيمى به سبب قابليت تكثير بالا، خودنوزايى و تمايز به انواع سلول از قابليت ترميم و بازسازى لئسي بافتهاى مختلف بدن، همجنين قابليت بيوند و تلفيق در بافتهاى آسيبديده برخوردارند (f). مطالعات كذشته نشان داده است سلولهاى بنيادى مزانشيمى بهطور جشمخيرى شكل گيرى اتوليزوزوم (تلفيق ليزوزومهاى اوليه

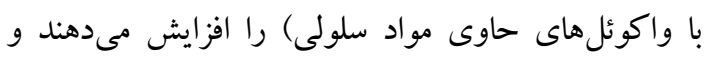

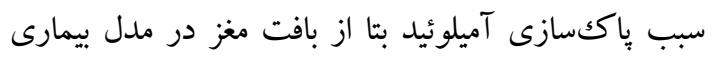
آلزايمر مىشوند (ها). از سوى ديخر، تحقيقات نشان داده

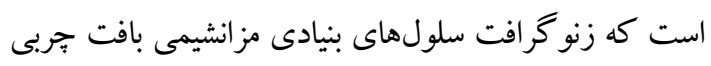
انسان سبب كاهش بيان فاكتورهاى نكرويتوتيك شبهيروتئين
بود (P<0.001). اين در حالى است كه بيوند سلولهاى بنيادى مزانشيمى بافت جربى سبب افزايش معنادار سطح

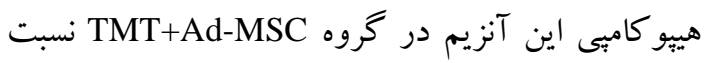

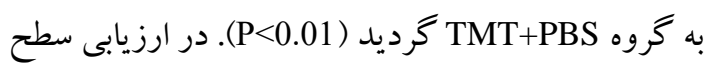
فعاليت آنزيم SOD نيز، كاهش معنادارى در كروه TMT+PBS

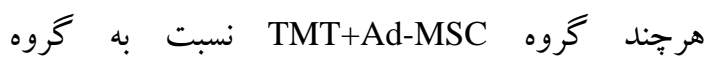
فMT+PBS

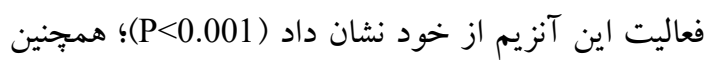
نتايج بيانكر آن بود كه تيمار با TMT سبب كاهش فرد فعاليت

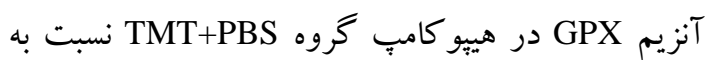
گروه كنترل مى گردد ( درون وريدى سلولهاى بنيادى، سطح فعاليت اين آنزيم

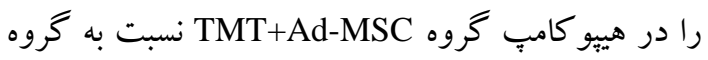
TMT+PBS، بهصورت معنادارى افزايش داد (P<0.05). سطح فاكتور MDA در گروه TMT+PBS نسبت به كروه كنترل افزايش معنادارى را بيان كرد (P<0.001)،

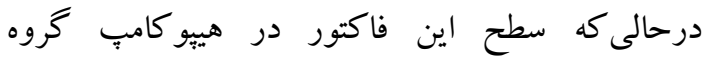
TMT+Ad-MSC TMT+PBS از خود نشان داد (P<0.01).

\section{بحث و نتيجه كيرى}

در مطالعة حاضر، به بررسى اثر بيوند سلولهاى بنيادى مزانشيمى بافت جربى انسان بر مؤلفههاى استرس

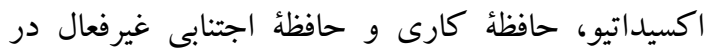
مدل حيوانى بيمارى آلزايمر برداخته شد. نتايج نشان داد 
مطالعٔ حاضر نشان داد كه متعاقب مسموميت با TMT با

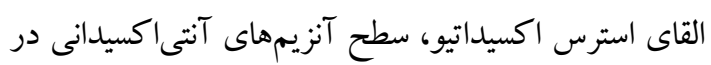

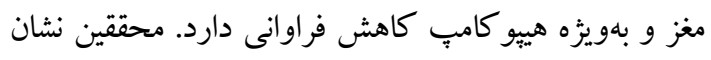

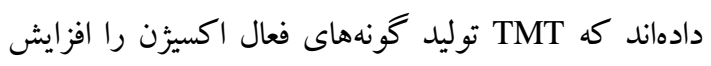
مىدهد و درنتيجه، موجب آسيب بافت مغز در موش

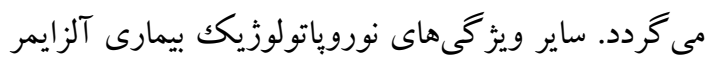

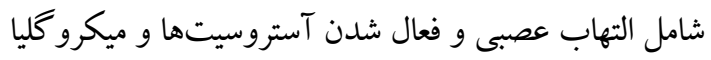
كه بهطورمعمول در يلاككهاى آميلوئيدى در مغز بيماران

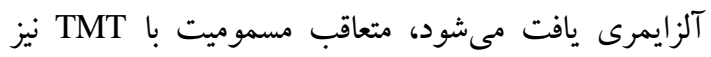
ديدهشده است (Y)؛؛ بنابراين، بر اساس مطالعه حاضر و

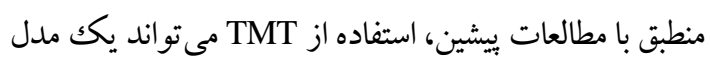

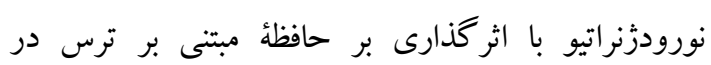
حيوانات القا كند و يكك روش بيشنهادى مناسب در مطالعات تخريب نورونى، اختلال حافظه و نقايص رفتارى مرتبط با عملكردهاى شناختى در مدلهاى حيو انى است.

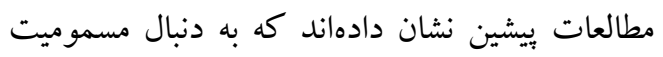
موشهاى صحرايى بTMT ، حافظة فضايى نيز بهشدت تخريب مىشود. ترىحمتيل حتين به تضعيف عملكرد

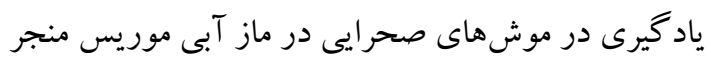

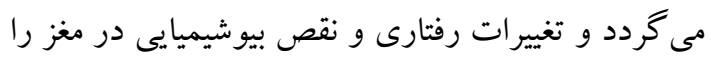

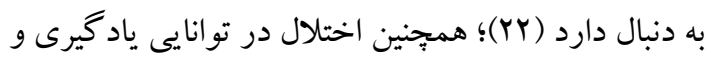
حافظه بهوسيلة كاهش خودبهخودى رفتار تناوبى در ماز

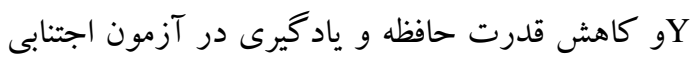
غيرفعال در مدل ترى-همتيل-تينى بيمارى آلزايمر

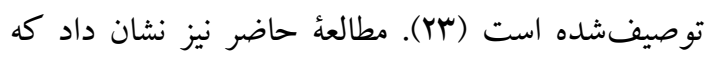
تزريق TMT بهطور معنادارى مدتزمان تأخير در آزمون

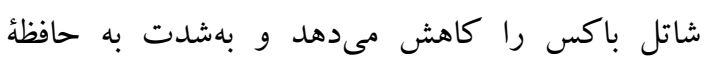
بلندمدت آسيب مىزند. يكى از علل آسيب به حافظة ودأ

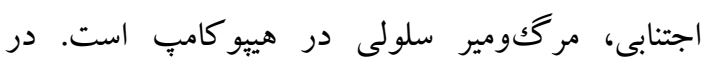
مطالعهاى، به دنبال تجويز TMT آسيب انتخابى به سلولهاى هرمى در CA3 و CA1 (به ميزان كمتر) هييو كامب مشاهدهشده است. ديدهشده است كه ده دوز

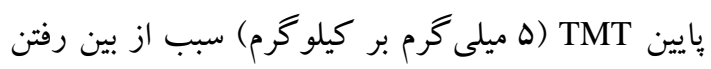

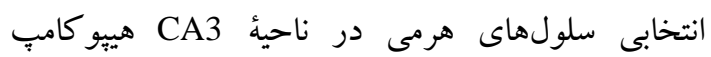

كينازى در مدل حيوانى بيمارى آلزايمر مى گردد (19).

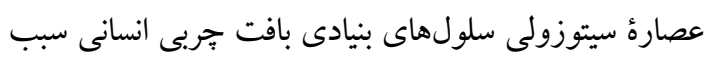

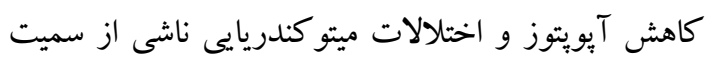

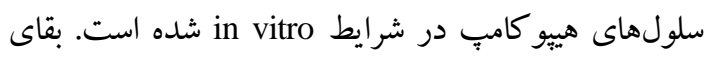

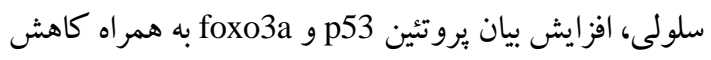

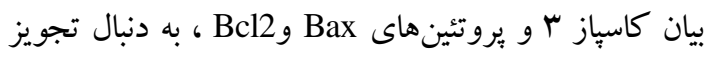

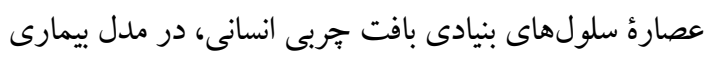

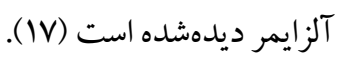
نتايج بهدست آمده از اين مطالعه نشان داد كه مسموميت الزيت

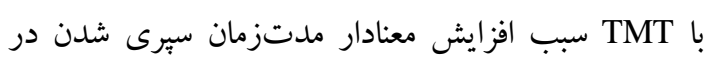
محفظة تاريكك(STD) ، كاهش تأخير در ورود به محفظة

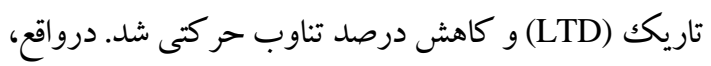

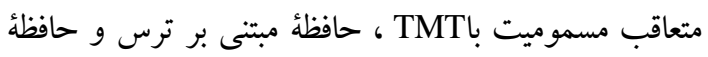

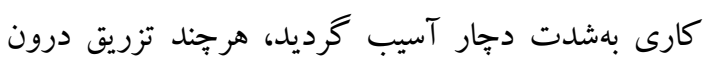
وريدى سلولهاى بنيادى مزانشيمى بافت جربى انسان باعث

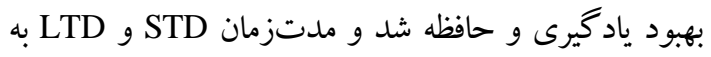

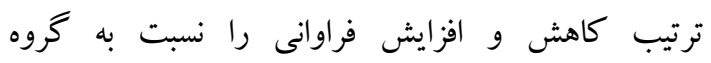
TMT+PBS حركتى را در ماز Y به شكل بارزى بهبود بخشيد. مطالعة

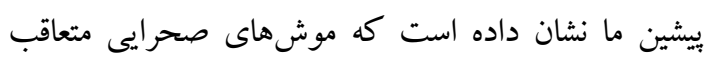

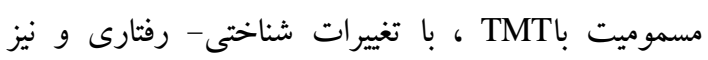

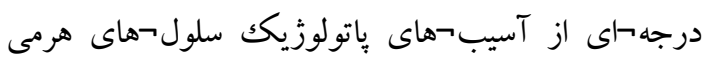

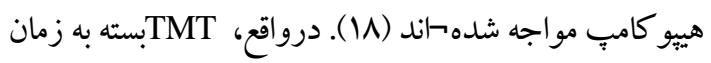
و غلظت استفادهده، به مرگك سلولى آيويتوزى در

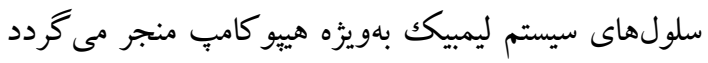

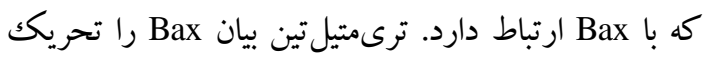
مى كند كه سبب تخريب غشاى ميتو كندرى و آزادسازى سيتو كروم C از ميتو كندرى به سيتوزول مى سشود كه بهنوئ

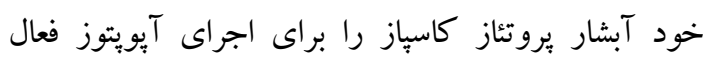

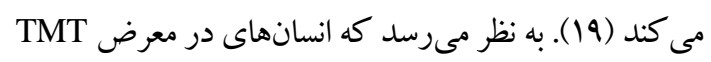

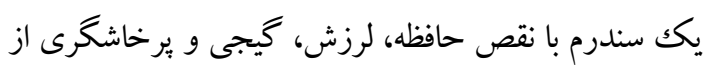

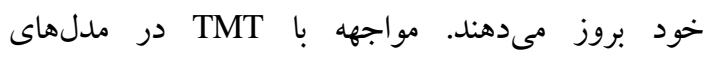

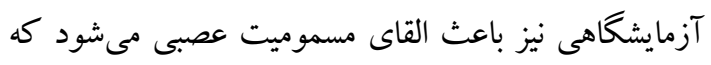

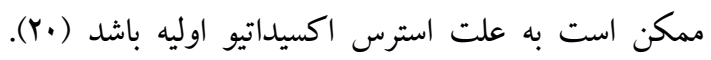


آنتىاكسيدانى را در مدل ايسكمى/ريبرفيوزن روده

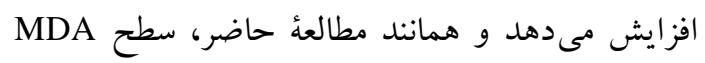
متعاقب بيوند سلولهاى بنيادى كاهش و سطوح فعاليت

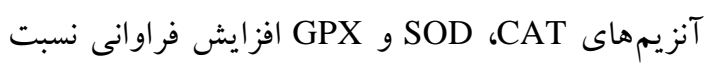
به گروه تيمارنشده داشته است (·r). در مطالعهُ حاضر، متعاقب بيوند زنو گر افت، بهبودى عملكردى در حافظه و ظرفيت آنتى اكسيدانى هيبو كامٍٍ احتمالاً نشاندهندهُ مهاجرت سلولهاى بنيادى بافت جربى انسان به ناحية آسيبديدهُ مغزى، آزادسازى فاكتورهاى ترشحى يا حتى جايخزينى با سلولهاى آسيبديده است، هرجند

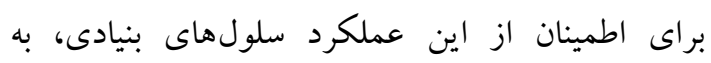
مطالعات دقيق سلولى - مولكولى و هيستوياتولوزيكى نياز است.

نتايج مطالعه حاضر از تخريب حافظه و يادگيرى متعاقب مسموميت با ترىمتيل تين بهعنوان مدلى از بيمارى آلزايمر و بهبود آن به دنبال بيوند سيستميك سلولهاى بنيادى بافت جربى انسان در موش هاى صحرايى نشان

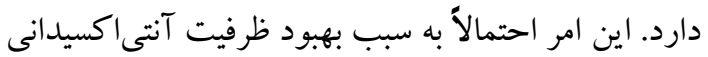
هييو كامب متعاقب تجويز سلولهاى بنيادى مزانشيمى مىتواند باشد؛ ازاينرو، مىتوان با شناخت بهتر ظرفيت آنتى اكسيداتيو سلولهاى بنيادى بافت جربى كام مهمى براى بهبود اختلالات شناختى ناشى از استرس اكسيداتيو نظير بيمارى آلزايمر برداشت.

تشكر و قدردانى

بدينوسيله از زحمات عزيزانى كه در نخارش اين مقاله همكارى داشتند، تشكر و قدردانى مى گردد.

\section{تعارض منافع}

نويسند كان اعلام مى كنند كه تضاد منافعى در اين

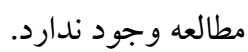

كد اخلاق: IR-IAUSHIRAZ- Irr-rd I r-qA
موشهاى صحرايى مى گردد و هنگامى كه دوز افزايش

مى يابد، آسيب سلولى به CA1 كسترش مى حيابد (YF). به نظر مىرسد كه جندين سازو كار مختلف ازجمله تمايز سلولهاى بيوندى به سلولهاى عصبى در شرايط in vivo كمو كاينها توسط سلولهاى بيوندى مىتوانند سبب بهبود ضايعات عصبى گردند (Yه). مطالعه بيشين ما نشان داده است كه بيوند سيستميك سلولهاى بنيادى مزانشيمى مغز استخوان اختلالات حر كتى و شناختى در مدل حيوانى دزنراسيون استرياتوم، بهعنوان مدلى از بيمارى هانتينگتون را بهبود مى بخشد (Y9). از آنجاكه

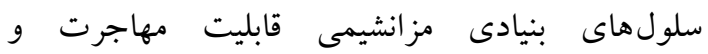
لانه گزينى بالايى به بافت آسيبديده متعاقب بيوند سيستميك دارند و نيز به علت دارا بودن قابليت

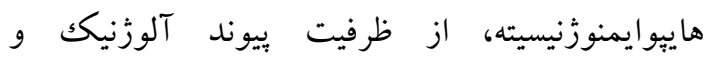
زنوزنيكك برخوردارند (rV) از آنجاكه التهاب ناشى از استرس اكسيداتيو فرايند كليدى در باتوفيزيولوزى اختلالات نورودزنر اتيو است و نقش سلولهاى بنيادى بافت جربى انسان بهعنوان يكك راهبرد جديد در حفاظت عصبى مطرحشده است، به نظر مىرسد اين سلولها قادرند با افزايش توان آنتىاكسيدانى سبب كاهش مرگك سلولى متعاقب استرس اكسيداتيو در شرايط in vitro شوند (YN). همانند مطالعه حاضر، فرفان و همكاران نشان دادند كه تجويز اينترانازال سلولهاى بنيادى مز انشيمى بافت جربى مىتواند استرس اكسيداتيو هييو كامٍ را كاهش دهد. اين سازو كار از طريق كاهش سطح كلوتاتيون بافتى، افزايش سطح فاكتور آنتى اكسيداتيو هستهاى NRF2 و افزايش يروتئين آنتى اكسيداتيو NQO1 به وقوع

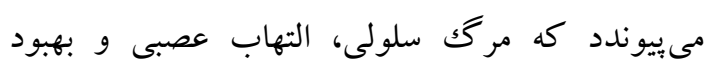
عملكرد رفتارى را در مدل آسفيكسياى يريناتال به دنبال دارد (Y9)؛ همجنين وبيوند موضعى و سيستميك سلولهاى بنيادى مزانشيمى مغز استخوان ظرفيت

\section{References}


1. Ferreira S, Raimundo AF, Menezes R, Martins IC. Islet amyloid polypeptide and amyloid beta peptide roles in Alzheimer disease two triggers one disease. Neural Reg Res 2021; 16:1127-30. doi.10.4103/1673-5374.300323.

2. Loeffler DA. Modifiable non modifiable, and clinical factors associated with progression of Alzheimer disease. J Alzheimers Dis 2021; 80:127. doi.10.3233/JAD-201182.

3. Kwak KA, Lee SP, Yang JY, Park YS. Current perspectives regarding stem cell-based therapy for alzheimer disease. Stem Cell Int 2018; 2018:6392986. doi. 10.1155/2018/6392986.

4. Bagherimohammadi S. Stem cell based therapy as a promising approach in Alzheimer disease current perspectives on novel treatment. Cell Tis Bank 2021; 22:339-53. doi. 10.1007/s10561-02009896-3.

5. Pompili E, Fabrizi C, Fumagalli L, Fornai F. Autophagy in trimethyltin induced neurode generation. J Neural Transm Vien2020; 127:98798. doi.10.1007/s00702-020-02210-1.

6. Malekzadeh S, Edalatmanesh MA, Mehrabani D, Shariati M. Drugs induced alzheimer disease in animal model. Galen Med J 2017; 6:185-96. doi. 10.22086/gmj.v6i3.820.

7. Aboulhoda BE, Rashed LA, Ahmed H, Obaya EMM, Ibrahim W, Alkafass MAL, et al. Hydrogen sulfide and mesenchymal stem cells extracted microvesicles attenuate LPS-induced Alzheimer disease. J Cell Physiol 2021; 236: 5994-6010. doi.10.1002/jcp.30283.

8. Yazdanfar S K, Edalatmanesh MA. [Systemic transplantation of valproic acid primed human adipose stem cells on amelioration of motor deficits in animal model of cerebellar degeneration]. Sci J Kurdistan Uni Med Sci 2018; 23:77-90. (Persian)

9. Hosseini M, Moghadas M, Edalatmanesh MA, Hashemzadeh MR. Xenotransplantation of human adipose derived mesenchymal stem cells in a Rodent model of Huntington's disease motor and non-motor outcomes. Neurol Res 2015; 37:30919. doi.10.1080/01616412.2017.1298496.

10. Moghadas M, Edalatmanesh MA, Robati R. histopathological analysis from gallic acid administration on hippocampal cell density depression, and anxiety related behaviors in a trimethyltin intoxication model. Cell J 2016; 17:659-67. doi.10.22074/cellj.2016.3838.

11. Saberi Z, Edalatmanesh MA. [The effect of gallic acid on cognitive dysfunctions with intrauterine growth restriction in Rats]. Alborz Uni Med J 2019; 8:185-99. (Persian)

12. Edalatmanesh MA, Hosseini M, Ghasemi S, Golestani S, Sadeghnia HR, Mousavi SM, et al. Valproic acid mediated inhibition of trimethyltin induced deficits in memory and learning in the Rat does not directly depend on its anti oxidant properties. Ir J Med Sci 2016; 185:75-84. doi.10.1007/s11845-014-1224-y.

13. Edalatmanesh MA, Shahsavan S, Rafiei S, Khodabandeh H. [The effect of gallic acid on depression symptoms oxidative stress markers and inflammatory cytokines in Rats hippocampus after tmt intoxication an experimental study]. J Rafsanjan Uni Med Sci2018; 17:815-28. (Persian)
14. Wang YH, Guo YC, Wang DR, Liu JY, Pan J. adipose stem cell based clinical strategy for neural regeneration a review of current opinion. Stem Cell Int 2019; 2019:8502370. doi.10.1155/2019/ 8502370.

15. Shin JY, Park HJ, Kim HN, Oh SH, Bae JS, Ha $\mathrm{HJ}$, et al. Mesenchymal stem cells enhance autophagy and increase $\beta$ amyloid clearance in Alzheimer disease models. Autophagy 2014; 10:32-44. doi.10.4161/auto.26508.

16. Eftekharzadeh M, Simorgh S, Doshmanziari M, Hassanzadeh L, Shariatpanahi M. Human adipose derived stem cells reduce receptor interacting protein 1 receptor interacting protein 3 and mixed lineage kinase domain like pseudokinase as necroptotic markers in rat model of Alzheimer disease. Indian J Pharmacol 2020; 52:392-401. doi.10.4103/ijp.IJP_545_19.

17. Liu T, Lee M, Ban JJ, Im W, Mookjung I, Kim M. Cytosolic extract of human adipose stem cells reverses the amyloid beta induced mitochondrial apoptosis via p53/foxo3a pathway. PLos One 2017; 12:168859. doi. 10.1371/journal.pone.0168859.

18. Moghadas M, Edalatmanesh MA. Protective effect of lithium chloride against trimethyltin induced hippocampal degeneration and comorbid depression in Rats. Comp Clin Pathol 2014; 24:1165-75. doi.10.1007/s00580-014-2055-y

19. Mignini F, Nasuti C, Artico M, Giovannetti F, Fabrizi C, Fumagalli L, et al. Effects and trimethyltin on hippocampal dopaminergic markers and cognitive behaviour. Int $\mathbf{J}$ Immunopathol Pharmacol 2012; 25:1107-19. doi.10.1177/039463201202500428.

20. Zhang L, Li L, Prabhakaran K, Borowitz JL, Isom GE. Trimethyltin-induced apoptosis is associated with upregulation of inducible nitric oxide synthase and Bax in a hippocampal cell line. Toxicol Appl Pharmacol 2006; 216:34-43. doi. 10.1016/j.taap.2006.05.004.

21. Morita M, Imai H, Liu Y, Xu X, Sadamatsu M, Nakagami R, et al. FK506-protective effects against trimethyltin neurotoxicity in Rats hippocampal expression analyses reveal the involvement of periarterial osteopontin. Neuroscience 2008; 153: 1135-45. doi.10.1016/ j.neuroscience.2008.01.078.

22. Ye M, Han BH, Kim JS, Kim K, Shim I. Neuroprotective effect of bean phosphatidylserine on tmt induced memory deficits in a Rat model. Int J Mol Sci 2020; 21:4901. doi.10.3390/ijms 21144901.

23. Edalatmanesh M A, Sheikholeslami M, Rafiei S. [Evaluation of brain derived neurotrophic factor expression and spatial memory after valproic acid administration in animal model of hippocampal degeneration]. Feyz 2018; 22:283-91. (Persian)

24. Marchese E, Corvino V, Di Maria V, Furno A, Giannetti S, Cesari E, et al. The neuroprotective effects of $17 \beta$ estradiol pretreatment in a model of neonatal hippocampal injury induced by trimethyltin. Front Cell Neurosci 2018; 12:385. doi.10.3389/fncel.2018.00385.

25. Sasai N, Kadoya M, Ong Leechen A. Neural induction historical views and application to pluripotent stem cells. Dev Growth Dif 2021;63:26-37. doi.10.1111/dgd.12703. 
26. Edalatmanesh MA, Matin MM, Neshati Z, Bahrami AR, Kheirabadi M. Systemic transplantation of mesenchymal stem cells can reduce cognitive and motor deficits in Rats with unilateral lesions of the neostriatum. Neurol Res 2010; 32:166-72. doi.10.1179/174313209X409025.

27. Naderimeshkin H, Bahrami AR, Bidkhori HR, Mirahmadi M, Ahmadiankia N. Strategies to improve homing of mesenchymal stem cells for greater efficacy in stem cell therapy. Cell Biol Int 2015; 39:23-34. doi.10.1002/cbin.10378.

28. Garridopascual P, Alonsovarona A, Castro B, Buron M, Palomares T. Hydrogen peroxide preconditioned human adipose derived stem cells enhance the recovery of oligodendrocyte like cells after oxidative stress induced damage. Int $\mathrm{J}$ Mol Sci 2020; 21:9513. doi.10.3390/ijms21249513.

29. Farfan N, Carril J, Redel M, Zamorano M, Araya M, Monzon E, et al. Intranasal administration of mesenchymal stem cell secretome reduces hippocampal oxidative stress neuroinflammation and cell death, improving the behavioral outcome following perinatal asphyxia. Int J Mol Sci 2020; 21:7800. doi.10.3390/ijms21207800.

30. Inan M, Bakar E, Cerkezkayabekir A, Sanal F, Ulucam E, Subaşı C, et al. Mesenchymal stem cells increase antioxidant capacity in intestinal ischemia reperfusion damage. J Pediatr Surg 2017; 52:1196206. doi. 10.1016/j.jpedsurg.2016.12.024. 